\title{
Perbandingan Tampilan Produktivitas Sapi Peranakan Ongole dengan Limousin-Peranakan Ongole di Kabupaten Tuban, Jawa Timur
}

\section{(Comparison of Productivity Performance of Ongole Grade (PO) with Limousin-Ongole Grade (LimPO) in Tuban Regency, East Java)}

\author{
Nasuha, Sumadi, Dyah M \\ Fakultas Peternakan, Universitas Gadjah Mada, Yogyakarta \\ nasuhadvm87@gmail.com
}

\begin{abstract}
The objective of this study was to determine the comparison of PO and LimPO cattle in Tuban Regency, East Java on reproductive performance and body size. This research was expected to be used as information material for local government and can be used as references or studies. The study was conducted by survey method on 81 PO cattle farmers and 63 LimPO cattle farmers in three subdistricts in Tuban Regency, East Java from April to May 2019. The results of the study were descriptively analyzed and T-test analysis. Reproductive performance of PO and LimPO cattle were PPM (post partum mating): $5.48 \pm 2.23$ and 5.59 \pm 2.06 months, S/C (service per conception): $2.38 \pm 0.86$ and $2.60 \pm 0.81$ times and CI (calving interval): $16.94 \pm 2.19$ and $17.19 \pm 2.33$ months. The body sizes of PO and LimPO female cattle were body length (BL): $127 \pm 11.40$ and $137.17 \pm 5.56 \mathrm{~cm}$, wither height $(\mathrm{WH})$ : $121.00 \pm 8.64$ and $126.67 \pm 8.22 \mathrm{~cm}$, and chest girth (CG): $153.00 \pm 8.47$ and $167.17 \pm 11.89 \mathrm{~cm}$. The body sizes male cattle were BL: $137.67 \pm 10.28$ and $146.00 \pm 5.58 \mathrm{~cm}, \mathrm{WH}: 137.00 \pm 6.54$ and $137.25 \pm 5.51 \mathrm{~cm}$ and CG: $174.33 \pm 12.28$ and $187.75 \pm 10.17 \mathrm{~cm}$. In conclusion that the comparison of reproductive performance of PO and LimPO cattle was not significantly different $(\mathrm{P}>0.05)$ and LimPO cattle body size has a larger size than $\mathrm{PO}(\mathrm{P}<0.05)$.
\end{abstract}

Key words: Reproductive performance, body size, Ongole grade (PO), Limousin-Ongole grade (LimPO)

\begin{abstract}
ABSTRAK
Tujuan penelitian ini adalah mengetahui perbandingan ukuran tubuh dan reproduksi sapi PO dan LimPO di Kabupaten Tuban, Jawa Timur. Penelitian ini diharapkan dapat digunakan sebagai bahan informasi bagi pemerintah setempat dan bahan rujukan atau acuan penelitian berikutnya. Penelitian dilakukan dengan metode survei pada 81 peternak sapi PO dan 63 peternak sapi LimPO di tiga kecamatan di Kabupaten Tuban, Jawa Timur pada bulan April hingga Mei 2019. Hasil penelitian dianalisis secara deskriptif dan diuji dengan uji-t. Kinerja reproduksi induk sapi PO dan sapi LimPO adalah PPM (post partum mating): 5,48 $\pm 2,33$ bulan

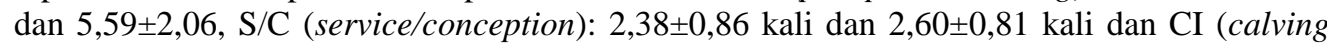
interval): $16,94 \pm 2,19$ bulan dan $17,19 \pm 2,33$ bulan. Ukuran tubuh sapi betina PO dan LimPO adalah panjang badan (PB): $127 \pm 11,40 \mathrm{~cm}$ dan $137,17 \pm 5,56 \mathrm{~cm}$, tinggi gumba (TG): $121,00 \pm 8,64 \mathrm{~cm}$ dan $126,67 \pm 8,22 \mathrm{~cm}$, dan lingkar dada (LD): $153,00 \pm 8,47 \mathrm{~cm}$ dan $167,17 \pm 11,89 \mathrm{~cm}$. Ukuran tubuh sapi jantan PO dan LimPO adalah PB: 137,67 $\pm 10,28 \mathrm{~cm}$ dan $146,00 \pm 5,58 \mathrm{~cm}$, TG: $137,00 \pm 6,54 \mathrm{~cm}$ dan $137,25 \pm 5,51 \mathrm{~cm}$, dan LD: $174,33 \pm 12,28 \mathrm{~cm}$ dan $187,75 \pm 10,17 \mathrm{~cm}$. Kesimpulan kinerja reproduksi sapi betina PO dan LimPO berbeda tidak
\end{abstract}


nyata $(\mathrm{P}>0,05)$, ukuran tubuh sapi LimPO memiliki ukuran lebih besar dari $\mathrm{PO}(\mathrm{P}<0,05)$ pada betina yaitu PB, TG, dan LD dan jantan untuk PB dan LD.

Kata kunci: Kinerja reproduksi, ukuran tubuh, Peranakan Ongole (PO), LimousinPeranakan Ongole (LimPO)

\section{PENDAHULUAN}

Sapi potong merupakan ternak penghasil daging yang memainkan peranan penting di Indonesia sebagai penghasil protein hewani. Konsumsi daging sapi di masyarakat selalu meningkat dari tahun ke tahun. Hal ini disebabkan oleh beberapa faktor, diantaraya bertambahnya populasi penduduk, meningkatnya kesadaran masyarakat akan gizi, dan meningkatnya penghasilan. Namun, peningkatan kebutuhan daging sapi tersebut tidak diimbangi dengan produksi daging sapi dalam negeri. Sehingga langkah yang dilakukan pemerintah untuk memenuhi kebutuhan tersebut dengan memberikan ijin importasi daging dan sapi bakalan. Oleh karena itu, program pengembangan sapi lokal diperlukan untuk mendukung swasembada daging di Indonesia. Indonesia memiliki potensi sapi lokal dan persilangan, beberapa di antaranya adalah sapi Peranakan Ongole (PO) dan Limousin-Peranakan Ongole (LimPO) yang tersebar di beberapa daerah di Indonesia. Salah satunya adalah Kabupaten Tuban sebagai salah satu sentra sapi potong di Provinsi Jawa Timur. Langkah pertama yang dapat dilakukan untuk mendukung program swasembada daging sapi adalah pengembangan ternak lokal dengan peningkatan jumlah populasi.

Upaya peningkatan populasi sapi potong dapat dilakukan dengan berbagai cara diantaranya adalah meningkatkan mutu genetik melalui seleksi dan efisiensi reproduksi melalui Inseminasi Buatan (IB) dan penanganan gangguan reproduksi. Inseminasi buatan adalah salah satu teknologi reproduksi yang mampu meningkatkan perbaikan mutu genetik ternak, sehingga dalam waktu singkat dapat menghasilkan anak dengan kualitas yang lebih baik dari induknya dalam jumlah yang besar dengan memanfaatkan pejantan unggul (Susilawati 2013). Parameter yang dapat digunakan untuk menilai penampilan reproduksi ternak adalah nilai service per conception $(\mathrm{S} / \mathrm{C})$, calving interval $(\mathrm{CI})$, dan post partum mating (PPM). Seleksi merupakan suatu upaya perbaikan performans ternak yang dapat dilakukan melalui pemilihan calon-calon tetua atau seleksi calon pejantan atau seleksi calon induk (Hardjosubroto 1994). Informasi ukuran tubuh sapi ini dapat dijadikan sebagai informasi dasar untuk program seleksi. Ukuran tubuh yang dapat digunakan sebagai alat seleksi diantaranya adalah panjang badan, tinggi gumba, dan lingkar dada.

Beberapa penelitian yang menunjukkan kinerja reproduksi telah dilakukan pada beberapa bangsa sapi di Indonesia, diantaranya sapi Aceh (Novita et al. 2018), sapi Sumba Ongole (Aji et al. 2017), sapi PO dan Peranakan Limousin (Yulyanto et al. 2014), dan sapi Peranakan Simmental (Iswoyo 2006). Penelitian ukuran tubuh sapi potong telah dilakukan sebelumnya, diantaranya sapi Pasundan (Sulasmi et al. 2017), dan sapi Bali (Hikmawaty et al. 2014). Sehingga perlu melakukan penelitian terkait kinerja reproduksi dan ukuran tubuh pada sapi PO dan LimPO di Kabupaten Tuban sebagai salah satu sentra sapi potong di Jawa Timur. Penelitian ini bertujuan untuk mengetahui perbandingan penampilan produktivitas berupa kinerja reproduksi dan ukuran tubuh sapi PO dan LimPO di peternakan rakyat Kabupaten Tuban, Jawa Timur. 


\section{MATERI DAN METODE}

\section{Waktu dan tempat penelitian}

Penelitian ini dilakukan pada tanggal 3 April - 25 Mei 2019 di Tiga Kecamatan, yaitu Kecamatan Kerek, Kecamatan Palang dan Kecamatan Tuban, Kabupaten Tuban Jawa Timur.

\section{Materi dan metode penelitian}

Materi yang digunakan untuk mengetahui kinerja reproduksi adalah data hasil wawancara terhadap 81 peternak sapi PO dan 63 peternak sapi LimPO. Metode yang digunakan dalam penelitian ini adalah observasi. Metode penentuan lokasi penelitian ditentukan secara purposive sampling dimana peneliti melihat pertimbangan waktu, kemampuan dan jangkauan (Notohadiprawiro 2006). Lokasi penelitian adalah tiga kecamatan yaitu Kecamatan Kerek, Kecamatan Palang, dan Kecamatan Tuban. Data yang diambil merupakan data primer. Pengambilan data primer dilakukan dengan cara pengamatan langsung melalui wawancara menggunakan kuisioner terhadap peternak. Data primer yang digunakan meliputi: identitas peternak, kepemilikan ternak, dan variabel penampilan reproduksi ternak.

Sampel ukuran tubuh menggunakan 49 ekor sapi PO dan 38 ekor sapi LimPO yang ada di peternak. Jumlah sampel yang diamati tersaji pada Tabel 2. Sapi yang dipilih sebagai sampel adalah sapi dewasa tubuh (jantan dan betina) pada kisaran umur lebih dari 2 tahun atau minimal sudah poel 1 pasang pada gigi bawah seri. Peralatan yang digunakan untuk mengukur peubah pada sapi adalah pita meteran, tongkat ukur, alat tulis dan kamera digital. Pengukuran dilakukan ketika ternak dalam kondisi berdiri normal. Metode pengukuran berdasarkan Badan Standarisasi Nasional (2015): a) Tinggi gumba, diukur jarak dari permukaan yang rata sampai bagian tertinggi pundak melewati bagian scapulla secara tegak lurus, menggunakan tongkat ukur; b) Panjang badan, diukur jarak dari bongkol bahu (tuberositas humeri) sampai ujung tulang duduk (tuber ischii), menggunakan tongkat ukur; c) Lingkar dada, diukur dengan melingkarkan pita ukur pada bagian dada dibelakang punuk diukur melingkar di sekeliling rongga dada melalui belakang punuk dalam satuan $\mathrm{cm}$.

\section{Parameter penelitian}

Parameter kinerja reproduksi yang diukur dalam penelitian ini meliputi: Post partum mating (PPM) merupakan jarak waktu perkawinan pertama setelah beranak (Wahyudi 2014), satuan bulan; Service/conception (S/C) merupakan jumlah pelayanan inseminasi yang dibutuhkan oleh seekor betina hingga terjadi kebuntingan, satuan yang digunakan adalah kali (Toelihere 1981); Calving interval (CI) dihitung dari catatan waktu beranak ke beranak berikutnya (Wahyudi 2014), satuan yang digunakan adalah bulan.

Parameter ukuran tubuh yang diukur dalam penelitian ini adalah panjang badan, tinggi gumba, dan lingkar dada yang dihitung dalam satuan $\mathrm{cm}$.

\section{Analisis data}

Data yang diperoleh selanjutnya dianalisis secara deskriptif dan statistik. Analisis deskriptif digunakan untuk mengetahui rataan dan standar deviasi dari kinerja reproduksi 
berupa post partum mating (PPM), service/conception (S/C) dan calving interval (CI) dan ukuran tubuh berupa panjang badan, tinggi gumba, dan lingkar dada. Selanjutnya dilakukan uji-t tidak berpasangan untuk mencari perbedaan pada parameter kinerja reproduksi dan ukuran tubuh tersebut antara sapi PO dan LimPO.

Ukuran tubuh sapi PO dan LimPO yang diteliti sebelum melakukan perbandingan distandarisasi ke dalam kelompok umur 3 tahun sesuai dengan Sumantri et al. (2007) dengan rumus sebagai berikut:

$$
\chi_{i-\text { terkoreks } i}=\frac{\bar{\chi} s \tan \text { dar }}{\bar{\chi} \text { pengamatan }} \times \chi \text { pengamatan } k e-i
$$

$$
\begin{array}{ll}
\text { Keterangan : } & =\text { ukuran ke-i yang terkoreksi, } \\
\chi_{\text {i-terkoreksi }} & =\text { ukuran pengamatan ke- } 1, \\
\frac{\chi}{\chi} \text { pengamatan } k e-i \tan d a r & =\text { rataan sampel umur } 3 \text { tahun } \\
\frac{\chi}{\chi} \text { pengamatan } & =\text { rataan sampel yang di amati } .
\end{array}
$$

\section{HASIL DAN PEMBAHASAN}

Hasil penelitian kinerja reproduksi sapi PO dan LimPO berupa service per conception (S/C), calving interval (CI), dan post partum mating (PPM) di Kabupaten Tuban dapat dilihat pada Tabel 1.

Tabel 1. Kinerja reproduksi sapi PO dan LimPO di Kabupaten Tuban

\begin{tabular}{lcccc}
\hline \hline Jenis Sapi & $\mathrm{N}$ & $\begin{array}{c}\text { Service per } \\
\text { conception }(\mathrm{S} / \mathrm{C}) \\
(\mathrm{kali})\end{array}$ & $\begin{array}{c}\text { Post partum mating } \\
(\mathrm{PPM})(\mathrm{bulan}) \\
(\mathrm{X} \pm \mathrm{Std})\end{array}$ & $\begin{array}{c}\text { Calving interval } \\
(\mathrm{CI}) \text { (bulan) } \\
(\mathrm{X} \pm \text { Std })\end{array}$ \\
\hline PO & 103 & $2,38 \pm 0,86$ & $5,48 \pm 2,33$ & $16,94 \pm 2,19$ \\
LimPO & 80 & $2,60 \pm 0,81$ & $5,59 \pm 2,06$ & $17,19 \pm 2,33$ \\
\hline
\end{tabular}

$\mathrm{N}=$ Jumlah sampel, $\mathrm{X}=$ Rataan, $\mathrm{Std}=$ Standard deviasi

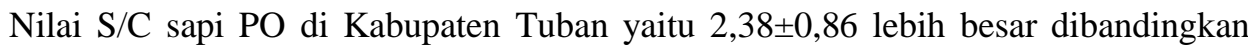
nilai S/C menurut Riyanto et al. (2015) dan Wahyudi (2014) masing-masing 1,52 $\pm 0,19$

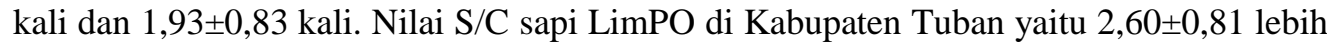
besar dibandingkan nilai S/C menurut Riyanto et al. (2015) dan Yulyanto et al. (2014) masing-masing 1,74 $\pm 0,07$ kali dan 1,52 $\pm 0,39$ kali. Hasil penelitian menunjukan bahwa nilai S/C sapi PO dan LimPO lebih tinggi dari 2 kali yang menunjukkan nilai S/C melebihi nilai normal. Menurut Toelihere (1981), S/C normal sapi induk yaitu berkisar antara 1,6 sampai 2,0 kali. Besar kecilnya nilai S/C dalam IB dipengaruhi oleh beberapa faktor, diantaranya ketidaktelitian deteksi estrus oleh peternak dan ketidaktepatan waktu IB oleh inseminator (Nurkhafid 2009), gangguan reproduksi dan induk kekurangan nutrisi (Hardjopranjoto 1995). Hasil uji-t tidak berpasangan menunjukkan perbedaan tidak nyata $(\mathrm{P}>0,05)$ pada nilai $\mathrm{S} / \mathrm{C}$ sapi PO dan LimPO di Kabupaten Tuban. Menurut Yulyanto et al. (2014), Sapi Persilangan Limousin (LimPO) di Indonesia memiliki nilai S/C yang hampir sama dengan sapi PO. Hal ini dikarenakan sapi persilangan Limousin 
merupakan sapi hasil persilangan dengan sapi PO yang sudah beradaptasi dengan kondisi lingkungan di Indonesia.

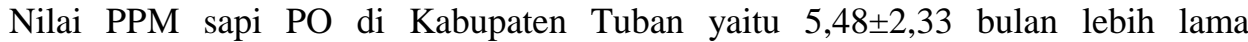
dibandingkan nilai PPM menurut Riyanto et al. (2015) 4,42 $\pm 1,23$ bulan dan lebih pendek dibandingkan Wahyudi (2014) 6,85 $\pm 4,10$ bulan. Nilai PPM sapi LimPO di Kabupaten Tuban yaitu 5,59 2,06 lebih lama dibandingkan nilai PPM menurut Riyanto et al. (2015)

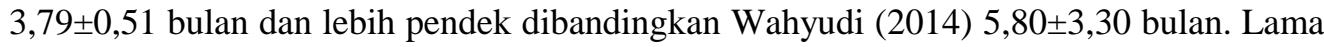
PPM sapi PO dan LimPO ini melebihi waktu seharusnya induk dikawinkan setelah beranak. Salisbury \& Vandemark (1985) menyatakan bahwa sapi betina seharusnya dikawinkan 60-80 hari atau 2-2,5 bulan setelah beranak karena diperlukan waktu minimal 50-60 hari atau 1,5-2 bulan untuk mencapai involusi uteri yang sempurna pada sapi. Peternak melakukan penundaan perkawinan setelah beranak dimaksudkan untuk memperbaiki skor kondisi tubuh induk dan menunda penyapihan pedet. Hasil uji-t tidak berpasangan menunjukkan perbedaan tidak nyata $(\mathrm{P}>0,05)$ pada nilai PPM sapi PO dan LimPO di Kabupaten Tuban. Nilai calving interval (CI) sapi PO di Kabupaten Tuban yaitu $16,94 \pm 2,19$ bulan lebih lama dibandingkan nilai CI menurut Riyanto et al. (2015)

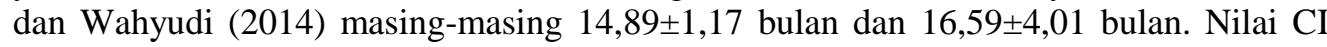
sapi LimPO di Kabupaten Tuban yaitu 17,19 $\pm 2,33$ lebih lama dibandingkan nilai CI menurut Riyanto et al. (2015) dan Yulyanto et al. (2014) masing-masing 14,44 $\pm 0,66$ bulan dan 15,04 $\pm 0,64$ bulan. Lama CI yang baik adalah 12 bulan, dimana 9 bulan bunting dan 3 bulan menyusui. Periode CI menggambarkan kemampuan induk sapi menghasilkan pedet dalam suatu ukuran waktu. Beberapa faktor yang memengaruhi CI adalah post partum estrus (PPE), PPM), dan S/C (Winarti \& Supriyadi 2010). Semakin lama PPE, PPM, dan besarnya nilai S/C maka semakin lama jarak beranak sapi tersebut. Iskandar \& Farizal (2011) menambahkan bahwa faktor yang mempengaruhi lamanya CI adalah kondisi lingkungan dan manajemen pemberian pakan. Hasil uji-t tidak berpasangan menunjukkan perbedaan tidak nyata $(\mathrm{P}>0,05)$ pada nilai $\mathrm{CI}$ sapi PO dan LimPO di Kabupaten Tuban.

Hasil penelitian ukuran tubuh sapi PO dan LimPO di Kabupaten Tuban dapat ditunjukkan pada Tabel 2.

Tabel 2. Ukuran tubuh sapi PO dan LimPO di Kabupaten Tuban

\begin{tabular}{lllccc}
\hline \hline $\begin{array}{l}\text { Jenis } \\
\text { sapi }\end{array}$ & $\begin{array}{l}\text { Jenis } \\
\text { kelamin }\end{array}$ & $\mathrm{N}$ & $\begin{array}{c}\text { Panjang badan } \\
(\mathrm{X} \pm \text { Std })\end{array}$ & $\begin{array}{c}\text { Tinggi gumba } \\
(\mathrm{X} \pm \text { Std })\end{array}$ & $\begin{array}{c}\text { Lingkar dada } \\
(\mathrm{X} \pm \text { Std })\end{array}$ \\
\hline PO & Betina & 31 & $127,00 \pm 11,40^{\mathrm{a}}$ & $121,00 \pm 8,64^{\mathrm{a}}$ & $153,00 \pm 8,47^{\mathrm{a}}$ \\
& Jantan & 18 & $137,67 \pm 10,28^{\mathrm{a}}$ & $137,00 \pm 6,54^{\mathrm{a}}$ & $174,33 \pm 12,28^{\mathrm{a}}$ \\
\multirow{2}{*}{ LimPO } & Betina & 17 & $137,17 \pm 5,56^{\mathrm{b}}$ & $126,67 \pm 8,22^{\mathrm{b}}$ & $167,17 \pm 11,89^{\mathrm{b}}$ \\
& Jantan & 21 & $146,00 \pm 5,58^{\mathrm{b}}$ & $137,25 \pm 5,51^{\mathrm{a}}$ & $187,75 \pm 10,17^{\mathrm{b}}$ \\
\hline
\end{tabular}

Superskrip huruf kecil berbeda pada jenis kelamin yang sama dan kolom yang sama menyatakan berbeda nyata $(\mathrm{P}<0,05), \mathrm{n}=$ jumlah sampel, $\mathrm{X}=$ Rataan, $\mathrm{Std}=$ Standard deviasi

Ukuran tubuh sapi LimPO memiliki ukuran lebih besar dari sapi $\mathrm{PO}(\mathrm{P}<0,05)$. Pada sapi betina yaitu PB, TG, dan LD, dan jantan pada PB dan LD. Gunawan et al. (2008) menyatakan bahwa perbedaan ukuran-ukuran tubuh dapat disebabkan karena faktor genetik maupun perbedaan lingkungan diantaranya manajemen pemeliharaan. Sapi LimPO berasal dari persilangan sapi induk PO dengan pejantan Limousin melalui program inseminasi buatan (IB). sapi Limousin merupakan sapi Bos taurus yang 
memiliki sifat pertumbuhan lebih cepat dan ukuran tubuh lebih besar dibandingkan sapi lokal PO. Perbedaan ukuran tubuh ini kemungkinan disebabkan karena faktor genetik karena peternakan rakyat khususnya di Kabupaten Tuban memiliki persamaan manajemen dalam pemberian pakan, yaitu sumber pakan berasal dari limbah pertanian maupun rumput lapangan yang ada di sekitar.

\section{KESIMPULAN}

Disimpulkan bahwa kinerja reproduksi yang meliputi S/C (service per conception), PPM (post partum mating), dan CI (calving interval) sapi betina PO dan sapi LimPO di Kabupaten Tuban tidak berbeda nyata. Ukuran tubuh sapi LimPO di Kabupaten Tuban lebih besar dibandingkan sapi PO.

\section{UCAPAN TERIMA KASIH}

Ucapan terima kasih kami sampaikan kepada Lembaga Pengelola Dana Keuangan (LPDP), Kementerian Keuangan Republik Indonesia atas bantuan pendanaan penelitian ini serta Dinas Perikanan dan Peternakan Kabupaten Tuban atas segala bantuan tenaga, data, dan fasilitas selama melakukan penelitian di Kabupaten Tuban, sehingga penelitian ini berjalan dengan baik.

\section{DAFTAR PUSTAKA}

Aji RN, Panjono, Ali A, Budi PW, Tety H, I Gede SB, Ismaya, Sigit B. 2017. Kinerja reproduksi sapi betina Sumba Ongole yang diinseminasi dengan semen beku sapi jantan Belgian blue. Buletin Peternakan. 41:379-384.

Badan Standarisasi Nasional. 2015. Standar Nasional Indonesia (SNI 7651.5: 2015) Tentang Bibit Sapi Potong-Bagian 5: Peranakan Ongole [Internet]. [cited 11 Juli 2019]. Available from: http://www.bsn.go.id.

Gunawan A, Jamal K, Sumantri C. 2008. Pendugaan bobot badan melalui analisis morfometrik dengan pendekatan regresi terbaik Best Subset pada domba garut tipe pedaging, tangkas dan persilangannya. Majalah Peternakan. 11:1-6.

Hardjopranjoto W. 1995. Ilmu Kemajiran Ternak. Surabaya (Indonesia): Universitas Airlangga Press.

Hardjosubroto W. 1994. Aplikasi Pemuliabiakan Ternak di Lapangan. Jakarta (Indonesia): Grasindo.

Hikmawaty Gunawan A, Noor RR, Jakaria. 2014. Identifikasi ukuran tubuh dan bentuk tubuh sapi Bali di beberapa pusat pembibitan melalui pendekatan analisis komponen utama. JPTHP. 2:231-237.

Iskandar, Farizal. 2011. Prestasi reproduksi sapi persilangan yang dipelihara di dataran rendah dan dataran tinggi Jambi. Jurnal Penelitian Universitas Jambi Seri Sains. 13:2528.

Iswoyo, Widyaningrum P. 2008. Performans reproduksi sapi Peranakan Simmental (PSM) hasil inseminasi buatan di Kabupaten Sukoharjo Jawa Tengah. JIIP. 11:125-133.

Notohadiprawiro T. 2006. Pertanian lahan kering di Indonesia: Potensi, Prospek, Kendala dan Pengembangannya. Yogyakarta (Indonesia): Universitas Gadjah Mada Press.

Novita CI, Eka MS, Erlisa R. 2018. Karakterisasi penampilan reproduksi sapi aceh betina sebagai sumber daya genetik ternak lokal di Kota Subulussalam. Agripet. 18:36-40. 
Nurkhafid. 2009. Kinerja reproduksi sapi induk peranakan ongole dan silangan simmental dengan peranakan ongole di Kecamatan Wates Kabupaten Kulon Progo [Skripsi]. [Yogyakarta (Indonesia)]: Universitas Gadjah Mada.

Riyanto J, Lutojo, Barcelona DM. 2015. Kinerja reproduksi sapi potong pada usaha peternakan rakyat di Kecamatan Mojogedang. 2015. Sains Peternakan. 13:73-79.

Salisbury GW, Vandemark RD. 1985. Fisiologi reproduksi dan inseminasi buatan pada sapi. Yogyakarta (Indonesia). Gadjah Mada University Press.

Sulasmi, Asep G, Rudi P, Cece S, Johar A. 2017. Keseragaman dan kedekatan morfometrik ukuran tubuh sapi Pasundan. J Veteriner. 18:263-273.

Sumantri C, Einstiana A, Salamena JF, Inounu I. 2007. Keragaan dan hubungan phylogenik antar domba lokal di Indonesia melalui pendekatan analisis morfologi. JITV. 12:42-54.

Susilawati T. 2013. Pedoman inseminasi buatan pada ternak. Malang (Indonesia): Penerbit Universitas Brawijaya Press

Toelihere MR. 1981. Fisiologi reproduksi pada ternak. Bandung (Indonesia): Angkasa.

Wahyudi RP. 2014. Penampilan reproduksi sapi induk Peranakan Ongole dan silangan Simmental dengan Peranakan Ongole di Kecamatan Nguter Kabupaten Sukoharjo [Skripsi] [Surakarta (Indonesia)]: Fakultas Peternakan Universitas Sebelas Maret.

Winarti E, Supriyadi. 2010. Penampilan reproduksi ternak sapi potong betina di Daerah Istimewa Yogyakarta. Prosiding Seminar Nasional Teknologi Peternakan dan Veteriner. Bogor (Indonesia): Pusat Penelitian dan Pengembangan Peternakan.

Yulyanto CA, Trinil S, Ihsan MN. 2014. Penampilan reproduksi sapi Peranakan Ongole (PO) dan sapi Peranakan Limousin di Kecamatan Sawoo Kabupaten Ponorogo dan Kecamatan Tugu Kabupaten Trenggalek. JIIP. 24:49-57. 